\title{
The Scholarly Atlantic \\ Circuits of Knowledge between Britain, the Dutch Republic \\ and the Americas in the Eighteenth Century
}

\author{
Karel Davids
}

On 30 August 1735, Johan Frederik Gronovius in Leiden wrote to his friend and fellow-naturalist Richard Richardson in Bierley, England, "You will remember that at the time you arrived here in town, you met at Mr. Lawson's a gentleman from Sweden, that went the same night to Amsterdam, where he is printing his Bibliothecam Botanicam. His name is Carolus Linnaeus." Gronovius went on to praise Linnaeus' singular learning "in all parts of natural history" and the excellent qualities of his new taxonomy of minerals, plants and animals. Gronovius predicted that "all the world" would especially be "much pleased" with his "Botanic Table," although he expected that it would take time "before one can know the right use," and it might thus "be rejected" by those who would not be prepared to devote some time to study it. ${ }^{1}$ Gronovius himself was so impressed by the significance of Linnaeus' achievement that he not only helped to see several of works of Linnaeus through the press in the Netherlands but also decided to reorder a survey of the "plants, fruits, and trees native to Virginia" sent to him in manuscript by John Clayton of Virginia shortly before, according to Linnaeus' system of classification, and publish it as the Flora Virginica in 1739/1743. This was the first comprehensive overview of the flora in this British American colony to appear anywhere. ${ }^{2}$

The story of Gronovius, Linnaeus and the Flora Virginica illustrates the main theme of this essay, namely the increasing connectedness between circuits of knowledge in the North Atlantic in the eighteenth century and the prominent role of actors in the Dutch Republic in the emergence and evolution of these networks. I conceive of "knowledge" both in the meaning of

1 Johan Frederik Gronovius to Richard Richardson, 30 August 1735, in Extracts from the literary and scientific correspondence of Richard Richardson, M.D., F.R.S. (Yarmouth: Charles Sloman, 1835), 343-345.

2 Flora Virginicia exhibens plantas quas V.C. Johannes Clayton in Virginia observavit et collegit, easdem methodo sexuali disposuit, ad genera propria retulit, nominibus specificis insignivit et minus cognitas descripsit Joh. Fred. Gronovius, 2 vols. (Leiden: Cornelis Waak, 1739-1743); Raymond Phineas Stearns, Science in the British colonies of America (Urbana, Ill.: University of Illinois Press, 1970) 556-557; Joan K. Stemmler, "A brief note on the authorship of the first Flora Virginica: Clayton, Gronovius and Linnaeus," Virginia Journal of Science 55 (2004): $125^{-134 .}$

(C) KAREL DAVIDS, 2014 | DOI 10.1163/9789004271319_011

This is an open access chapter distributed under the terms of the Creative Commons

Attribution-Noncommercial 3.0 Unported (CC-BY-NC 3.0) License. 
kennen, knowledge by acquaintance of objects, namely from the senses by taste and experience, and in the meaning of weten, knowledge of causal explanation by reasoning. ${ }^{3}$ Scholarship can comprise both forms of knowledge.

Contrary to views in the Anglo-American literature, ${ }^{4}$ I will show that the evolution of knowledge networks in the North Atlantic in the eighteenth century was a more complex affair than just the bilateral exchange between British and the American colonials. It was more than an interaction between confident, established scholars in the imperial metropolis and restless outsiders from New York, Philadelphia or Charleston trying to make a name for themselves in the wider world. European continentals, for a start, were deeply involved in networking. Moreover, players on both sides of the Atlantic not only entertained bilateral relations, but often corresponded with people in more than one region at the same time. Multilateral relationships, as in the case of Gronovius, were by no means uncommon. And these sorts of relationships developed not just between actors based in Britain, the Continent and the British American colonies, but also between American colonials or European continentals and people living in South America, notably in Dutch Guiana. In the course of the eighteenth century, networks of knowledge cut across different imperial spaces. This essay concentrates on connections between Britain, the Dutch Republic and the Americas, with occasional glances at Sweden, France and Italy. It does not deal with the networks of knowledge in the North Atlantic as a whole, including the contributions of Spain or Denmark. Such a comparative, overarching analysis is the subject of other studies. $^{5}$

Apart from increased connectedness between circuits of knowledge in a geographical sense, I will argue that the North Atlantic in the eighteenth century also saw a growth in connections in other respects. Circuits of knowledge

3 For this distinction, see Harold Cook, Matters of exchange. Commerce, medicine, and science in the Dutch Golden Age (New Haven: Yale University Press, 2007), 15, 20.

4 See e.g. Stearns, Science in the British colonies; John C. Greene, American science in the Age of Jefferson (Ames: Iowa State University Press, 1984); Joyce E. Chaplin, The first scientific American. Benjamin Franklin and the pursuit of genius (New York: Basic Books, 2006); Nick Wrightson, "[Those with] great abilities have not always the best information.' How Franklin's transatlantic book-trade and scientific networks interacted, ca. 1730-1757," Early American Studies 8 (2010): 94-119.

5 See Karel Davids, "Dutch and Spanish global networks of knowledge in the Early Modern Period:Structures, connections, changes," in Centres and cycles of accumulation in and around the Netherlands during the Early Modern Period, ed. Lissa Roberts (Berlin-Münster: LIT Verlag, 2011), 29-52; and my forthcoming book Ocean of knowledge: Globalization and the making of knowledge in the Atlantic world, c. 1680-1850. 
became more multipurpose, and were increasingly used for transmission of knowledge on different subjects, e.g. on natural history as well as on electricity or the behavior of water, winds and ocean currents. Moreover, crossborder exchange in a social sense occurred slightly more often than before. ${ }^{6}$ Connections increased between two sorts of circuits. In the first of these circuits, knowledge was usually recorded in printed verbal statements or visual representations of regularities, principles or general patterns. In this circuit, carriers of knowledge often came from the ranks of academics or members of learned societies, who communicated through written correspondence and journals of a scholarly or general nature. In the second circuit, knowledge often had a localized, site-specific nature and normally was memorized and transmitted orally rather than in written or printed form. Learning by watching, hearing and feeling was more common than learning by reading or writing. In this circuit, carriers of knowledge were often craftsmen, seamen, fishermen, peasants, hunters or common laborers, including slaves. In the eighteenth century, scholars (from circuit one) were often not only more interested in communicating with peers, but also showed themselves willing to learn from people outside the scholarly world, such as seamen or Native Americans (from circuit two).

Dutch actors have played a central role in the emergence and evolution of scholarly networks of knowledge. Although the continued existence of a (modest) colonial empire in the Atlantic was in this context not an entirely irrelevant factor, I will argue that colonial possessions were not a sine qua non for the role of Dutch actors in flows of knowledge. Cross-Atlantic networks of knowledge emerged and evolved in part independently from the existence of colonial empires.

How, then, did these scholarly networks of knowledge between Britain, the Dutch Republic and the Americas develop? What factors made their development possible and how can the key role of Dutch actors be explained?

6 However, this essay does not aim to engage with the voluminous body of literature on "local," "indigenous" or "subaltern" knowledge. See for example Walter D. Mignolo, Local histories/ Global designs. Coloniality, subaltern knowledges and border thinking (Princeton: Princeton University Press, 200o); Hugh Raffles, In Amazonia. A natural history (Princeton: Princeton University Press, 2002); Antonio Barrera-Osorio, "Local herbs, global medicines: commerce, knowledge and commodities in Spanish America," in Merchants and marvels. Commerce, science and art in Early Modern Europe, ed. Pamela H. Smith and Paula Findlen (New York: Routledge, 2002), 163-181; Londa Schiebinger, Plants and empire. Colonial bioprospecting in the Atlantic world (Cambridge ma: Harvard University Press, 2004); Stephen Snelders, Vrijbuiters in de heelkunde, op zoek naar medische kennis in de tropen (Amsterdam: Atlas, 2012). 
These are the central questions of this essay. The first section will discuss the emergence of connected circuits of knowledge up to the 1740s, the second section looks at flows of knowledge in these circuits between the 1740 s and the 1790 s and the third examines the facilities and forces that made these developments possible. The conclusion summarizes and discusses the findings of this article.

\section{Emerging Transatlantic Networks up to circa 1740}

The existing literature on transatlantic networks of knowledge in the early eighteenth century North Atlantic concentrates on the fledgling contacts between scattered groups of aspirant scientists in British colonies in America and established scholars in Britain, who were formally organized in the Royal Society of London. Raymond Phineas Stearns has described in detail how scientists in the American colonies gradually entered into regular contact with each other and with leading scientists in the metropolis and eventually managed to make contributions that were acknowledged as original and important by their overseas "mentors." While "colonial men of science" at first mainly served as "field workers" for scholars on the other side of the Atlantic, especially in the Royal Society of London, by 1770 they were able to "generate their own sources of inspiration, criticism and leadership," Stearns has argued. The formation of the American Philosophical Society in Philadelphia in the winter of $1768-1769$, modeled after the society in London, marked in his view the "crowning point" of this emancipation. ${ }^{7}$

Other historians have studied this development from the perspective of individual scientists or through the lens of particular fields of inquiry. Joyce Chaplin and Nick Wrightson have analyzed the career and connections of "the first scientific American," Benjamin Franklin. In a similar vein, Brooke Hindle has written a biography of the man who in the next generation succeeded Franklin as an icon of American scientific achievement, David Rittenhouse. ${ }^{8}$ James Delbourgo and Susan Scott Parrish have examined why people in the British American colonies in the eighteenth century came to be curious about

7 Stearns, Science in the British colonies, esp. xiii-xiv and 670.

8 Chaplin, Benjamin Franklin, Wrightson, "'[Those with] great abilities;" Brooke Hindle, David Rittenhouse (Princeton: Princeton University Press, 1964). The Mapping the Republic of Letters project at Stanford University has visualized Frnaklin's correspondence network from various angles, see http://republicofletters.stanford.edu/case-study/visualizing-benjamin -franklins-correspondence-network/. 
subjects such as electricity or natural history and how they acquired their knowledge. ${ }^{9}$

By the middle of the eighteenth century, the standard argument runs, an "intercontinental network of scientific communication" had arisen, which was "both continental [meaning: American, KD) and intercontinental in scope." "No longer were colonial scientists isolated from one another in a wilderness," Stearns has written. The network of learned correspondents had become much more extended and integrated than a few decades before. The growth of this transatlantic "community" can, according to these historians, be explained on the one hand by factors on the British side such as "the stimulating promotional activities of the Royal Society of London" and in particular the tireless coordinating efforts of Peter Collinson, and on the other hand, by factors on the American side such as the "widening public interest of the colonists themselves," "the societal growth of colonial institutions" and more specifically, the patient, methodical network-building by Benjamin Franklin. ${ }^{10}$

This conventional picture is not inaccurate, I would argue, but it is incomplete. Learned men from Continental Europe and other regions outside the British Atlantic world make an occasional appearance in these studies, but they are essentially relegated to the margins. The "Atlantic" or "transnational" dimension barely seems to extend beyond the borders of the Anglo-American world and the networks of knowledge are centered on Britain. The reality in the eighteenth century was different. The scholarly Atlantic was much larger than the colonial empire of Britain and it was a polycentric rather than a monocentric entity.

A cursory glance at the numerous volumes of edited correspondence of scholars on both sides of the Atlantic in the eighteenth century shows that exchange of knowledge went beyond the restrictions of the British mercantilist system. London was not in a privileged position as a destination for exports of knowledge from the American colonies. The genesis of the Flora Virginica is a telling case in point. John Clayton sent his items and descriptions not just to England, but also to a naturalist in the Dutch Republic, Johan Frederik Gronovius. It was Gronovius, not a British naturalist, who got Clayton's

9 James Delbourgo, A most amazing scene of wonders: Electricity and Enlightenment in Early America (Cambridge Mass.: Harvard University Press, 2006); Susan Scott Parish, American curiosity: Cultures of natural history in the Colonial British American world (Chapel Hill: University of North Carolina Press, 2006).

10 Stearns, Science in the British colonies, 534-535, Chaplin, Benjamin Franklin, 94-95; Wrightson, “[Those with] great abilities,"” 108, 113-114; Delbourgo, A most amazing scene of wonders, $17-22$. 
manuscript published. And even after Clayton had sent a complete manuscript for a new edition of the Flora to one of the leading botanists in Britain in 1757, Peter Collinson, it was not in London but in Leiden that the second edition of the book appeared. Collinson himself had for many years urged Gronovius Sr. to bring out a new edition of this "work so much wanted and so much desired."11

Networks of knowledge between the British American colonies and the European Continent came into being well before the middle of the 1730 . Linnaeus' arrival on the scene gave this development a powerful boost, ${ }^{12}$ but it did not create it. The emergence of these cross-Atlantic networks shows that colonial possessions were not a sine qua non for the role of Dutch actors in flows of knowledge. Cross-Atlantic networks of knowledge arose and evolved in part independently from the existence of colonial empires. The networking probably started soon after Herman Boerhaave in 1709 had succeeded Pieter Hotton as professor of botany and curator of the botanical garden at the University of Leiden. In 1722 Boerhaave got involved in a "crowd funding" scheme to support an expedition by botanist Thomas More to all colonies north of Virginia to collect "plants, seeds, fruits, barks, metalls...and all such other naturall bodies frequenting those countrys as ye unknown to us". The participants of this fund, organized by William Sherard, paid an annual contribution of one pound or one guinea. Apart from Boerhaave, all members came from Britain. ${ }^{13}$ Johan Frederik Gronovius entered into correspondence with another seasoned botanical traveler in the Americas, Mark Catesby, sometime before 1736. After collecting a vast amount of specimens in the Southern mainland colonies and the Bahamas in the 1720s, Catesby had returned to London

11 Peter Collinson to Johan Frederik Gronovius, 17 September 1756, in Forget not mee and my garden. . . Selected letters, 1725-1768, of Peter Collinson F.R.S., ed. Alan W. Armstrong (Philadelphia: American Philosophical Society, 2002) 201-202; see also Collinson to Gronovius, 23 March 1753, in idem, 166-168 and Collinson to Gronovius, 14 October 1755, in idem, 191-192. In contrast to Whitfield Bell, Patriot-improvers, 170-171. I think it unlikely that Laurens Theodoor Gronovius was unaware of the existence of Clayton's manuscript in England; after all, Collinson had written his father about it in September $175^{8}$ and Clayton's son, Thomas, had visited Holland in late $175^{8}$ or early 1759 ; see Collinson to Gronovius, 10 September 1758, and Collinson to Gronovius, 26 December 1758, in idem: Armstrong, ed., Forget not mee, 213-215.

12 Thanks to Linnaeus' voluminous correspondence, this networking is also clearly visible for the eye of the present-day historian. Letters to and from Linnaeus are now being made available in an electronic edition initiated by the Swedish Linnaeus Society and published by the Centre international d'étude du XVIIIe siècle; Ferney-Voltaire, The Linnaean Correspondence, http://linnaeus.c18.net.

13 Stearns, Science in the British colonies, 474. 
in 1726 . Gronovius kept corresponding with him until his death in $1749 \cdot{ }^{14}$ Another early American correspondent of Gronovius was Lewis Johnston in New York..$^{15}$

Scholars in the Dutch Republic depended for the supply of items from the natural world in the Americas not solely on correspondents in the British American colonies or on mediators in Britain, such as Sherard, Collinson or Catesby. The period before the 1730 s also saw the rise of a network between scholars in the Netherlands and "field workers" in Dutch colonies in the Americas, who supplied collectors in Britain as well as the Dutch Republic. In a letter from 1706 to Sir Hans Sloane, physician and Secretary of the Royal Society in London, Frederik Ruysch, professor of anatomy at the Athenaeum Illustre in Amsterdam, promised to send a specimen of a particular kind of toad from America, which Sloane had asked for. ${ }^{16}$ Ruysch must have had a contact in America based outside the British empire. Suriname definitely was a source of natural curiosities in the early eighteenth century. Butterflies and other insects from Suriname were offered to Sloane and James Petiver in London via Dutch collectors based in Haarlem and Rotterdam. ${ }^{17}$ An anonymous collector "ex Surinama" - identified as Isaac Augar, doctor of the hospital in Paramaribo - sent specimens of the local flora to Gronovius in $1736 .{ }^{18}$ Augar's successor at the hospital, Johann Bartsch, was hand-picked by Linnaeus himself to as an expert local correspondent for botanists in the metropolis. Despite Bartsch's untimely death, correspondence about natural history between the Dutch Republic and Dutch Guiana did not completely cease, as we will see shortly.

By the late 1740s, networks of knowledge between correspondents in the Dutch Republic and in the British American colonies were, judging by the

14 Gronovius to Carolus Linnaeus, 15 June 1736, The Linnaean Correspondence, linnaeus.c18. net, letter Loo89 (consulted 26 July 2012); Gronovius to John Bartram, 2 July 1750, in Memorials of John Bartram and Humphry Marshall, with notices of their botanical contemporaries, ed. William Darlington (Philadelphia: Lindsay and Blakiston, 1849), 358.

15 Lewis Johnston to Johan Frederik Gronovius, 20 November 1734, Koninklijke Bibliotheek The Hague [Dutch National Library] Ms. 121 D 6 no. 37.

16 Frederik Ruysch to Hans Sloane, 26 August 1706, Sir Hans Sloane's Correspondence Online. https://drc.usask.ca/projects/sloaneletters/doku.php?id=letter\&letterid=1270 (consulted 1 March 2013).

17 Daniel à Loenen to Hans Sloane, 30 July 1713, Sir Hans Sloane's Correspondence Online, https://drc.usask.ca/projects/sloaneletters/doku.php?id=letter\&letterid=1870 (consulted 1 March 2013); Eric Jorink, Het Boeck der Natuere. Nederlandse geleerden en de wonderen van Gods schepping 1571-1715 (Leiden: Primavera Press, 2006), 258.

18 D. Onno Wijnands and Johannes Heniger, "The origins of Clifford"s herbarium," Botanical Journal of the Linnean Society 106 (1991): 129-146, 142. 
frequency of contacts, almost as highly developed as those between American colonists and learned men in England. Some of the key American correspondents of Peter Collinson entered into direct contact with his friend in Holland, Johan Frederik Gronovius. This relationship was evidently beneficial for both sides. James Clayton in Virginia, John Bartram in Pennsylvania and Cadwallader Colden in New York sent Gronovius samples of plants, animals or minerals, told him about interesting visitors to their locale and occasionally ventured some new ideas of their own. Gronovius sent his American correspondents copies of books published in the Netherlands, kept them informed about recent or upcoming publications on natural history, commented on their findings and sometimes also asked for specific sorts of items.

Each of these correspondents could also serve as a link to other members of the Republic of Letters. Gronovius served for the Americans as a contact with European scholars such as Carolus Linnaeus, Petrus van Musschenbroek and Johannes Lulofs. ${ }^{19}$ Bartram acted for Gronovius as a go-between in America with their mutual friends, naturalists Phineas Bond and James Logan. ${ }^{20}$ Alexander Garden from Charleston, Carolina, was able to read letters from Collinson and Gronovius to Cadwallader Colden when visiting Colden in Coldengham, New York, in $1754 .{ }^{21}$ Colden and Bartram acted as intermediaries between Gronovius and Benjamin Franklin. ${ }^{22}$ It was Colden who sent Gronovius a copy of Franklin's description of his newly-invented fireplace, and it was Bartram who in 1746 received from Gronovius two copies of the Dutch translation of this tract, which, according to the Leiden physician, "hath found a great applause in this part of the

19 Gronovius to Cadwallader Colden, 6 August 1743, in Selections from the scientific correspondence of Cadwallader Colden with Gronovius, Linnaeus, Collinson and other naturalists, ed. Asa Gray (New Haven: B.L. Hamlen, 1843), 4-7, esp. 6; Colden to Gronovius (n.d., probably 1744), in idem, 9-16, esp. 9; Colden to Gronovius, 1 October 1755, in idem, 20-23, esp. 22; Gronovius to Bartram, 25 July 1744, in Darlington, ed., Memorials, 349-351, esp. $35^{\circ}$.

Bartram to Gronovius, 30 November 1743, in Darlington, ed., Memorials, 349; Bartram to Gronovius, 6 December 1745, in idem, $35^{2-353 .}$

21 Stearns, Science in the British colonies, 601.

22 Benjamin Franklin to Cadwallader Colden, February 1746, in The Papers of Benjamin Franklin, ed. Leonard W. Labaree et al. (New Haven: Yale University Press, 1961), 3:67; Franklin to Colden, 16 October 1746, in idem, 89; Gronovius sent his regards to Franklin via Bartram in 1754, see Gronovius to Bartram, 10 June 1754, in Darlington, ed., Memorials, 360-363, esp. 363; Franklin asked Gronovius via Bartram for copies of the Dutch translations of his tracts on the fireplace and on electricity, see Bartram to Gronovius, 3o November 1752, in idem, 359-36o, esp. 36o. 
world." ${ }^{23}$ This translation, made on the initiative of Gronovius himself, was in fact "Franklin's first overseas publication."24

\section{Flowing Knowledge, 1740s-1790s}

The story of the translation of Franklin's tract is also interesting in other respects. It illustrates how transatlantic circuits of knowledge which originally centered around exchange of information on natural history could serve as conduits for information about other subjects and it demonstrates that the interimperial exchange of knowledge after 1740 became more, not less common than before. From the 1740s onwards, flows of knowledge running between Britain, the British American colonies, the Dutch Republic and Dutch Guiana became wider and more varied. The frequency of interchange of knowledge between actors in these different parts of the North Atlantic increased, even though the importance of Anglo-Dutch trade for British American colonists diminished after the 1730 s. $^{25}$ The relative decline of the Netherlands as a center for the production of maps in the second quarter of the eighteenth century was not paralleled by a decreasing significance as a hub in transatlantic scholarly networks. ${ }^{26}$ The increased scholarly interaction across the Atlantic after 1740 can be observed in the circulation of knowledge on electricity and fish and on the behavior of water, winds and ocean currents.

\section{Electricity and Fish}

Although electrical phenomena had been known and observed for a long time, sustained research on electricity accelerated from the 1740 s onwards. It is the first field of study where American colonials made a distinct, generally

23 Colden to Gronovius (n.d., probably 1744), in Gray, ed., Selections, 9-18, esp. 15; Gronovius to Bartram, 2 June 1746, in Darlington, ed., Memorials, 354-357, esp. 355.

24 Chaplin, Benjamin Franklin, 96; on Gronovius' role, see his letter cited in the previous note. The English version of An account of the new invented Pennsylvania fire-place (Philadelphia: Franklin, 1744) can be found in The Papers of Benjamin Franklin, ed. Leonard W. Labaree et al., vol. 2 (New Haven: Yale University Press, 1960). I have not yet traced a copy of Dutch translation. Apparently, even Franklin's own library did not hold a copy; see Edwin Wolf and Kevin J. Hayes, eds., The library of Benjamin Franklin (Philadelphia: American Philosophical Society, 2006).

25 See the contribution by Christian Koot in this volume.

26 Cf. Benjamin Schmidt, Inventing Exoticism. Geography, Globalism, and Europe's Early Modern World. (Philadelphia: University of Pennsylvania Press, 2014). 
acclaimed contribution to science. The meteoric rise of Benjamin Franklin as a celebrated natural philosopher was first and foremost due to his experiments and observations on electricity, which earned him the award of the Copley Medal of the Royal Society in 1753 (the first colonial to receive this honor) and election as Fellow of the Society three years later. ${ }^{27}$ But the event that sped up the process of inquiry into electrical phenomena was a discovery made independently by a researcher in Germany, Ewald von Kleist, and a group of experimental philosophers at the university of Leiden in the Dutch Republic. It has become known as the invention of the Kleistsche Flasche or, more commonly, the "Leyden jar."

The "Leyden jar" consisted of a glass bottle coated with metal foil, which was partially filled with water and was provided with a metal wire passing through a stopper in its neck. The name "Leyden" derives from a description of experiments with this peculiar bottle in letters written by Petrus van Musschenbroek, professor of experimental physics in Leiden, to the secretary of the Académie des Sciences in Paris, René-Antoine de Réaumur, and to the leading French electrician Jean Nollet in January 1746, which soon circulated widely in the scholarly community in Europe. Shortly before, Van Musschenbroek, his colleague Jean Nicolas Sébastien Allamand and a visitor, Peter Cunaeus, had performed a series of trials with this device, which, unexpectedly, had generated a powerful, even terrifying, electrical discharge. ${ }^{28}$ The "Leyden jar" for the first time made it possible to store static electricity. Thanks to the easy accessibility of stored electrical charge, electrical experiments could from then on be conducted almost wherever and whenever one wished.

When news about the latest findings in Europe had reached colonial America, a group of Philadelphians, led by Franklin, from 1747 started to perform electrical experiments on their own, with the help of a glass tube sent by Peter Collinson and a generator supplied by the proprietor of Pennsylvania, Thomas Penn. ${ }^{29}$ The experiments conducted by Franklin and his fellowPhiladelphians in the late forties and early fifties led to many new insights in the study of electrical phenomena, such as the distinction between

27 Chaplin, The First Scientific American, 133-134, 155.

28 J.L. Heilbron, Electricity in the 17th and 18th centuries. A study of early modern physiology (Berkeley: University of California Press, 1979), 312-316; C. de Pater, Petrus van Musschenbroek (1692-1761), een newtoniaans natuuronderzoeker (Utrecht: Elinkwijk, 1979), 41-44.

29 Chaplin, The First Scientific American, 106; Delbourgo, A most amazing scene of wonders, 30-31. 
conductive and nonconductive materials, the distinction between "negative" and "positive" charge, the notions of circulation and equilibrium of electrical flows and the significance of pointed objects in conducting electricity (which eventually led to the invention of the lightning rod). Franklin described these in Experiments and observations on electricity, composed in the form of a series of essays addressed to Peter Collinson, which was first published in London in 1751 and went through four more English editions until 1774. French editions in $175^{2}$ and $175^{6}$ followed, plus another nine in Italian, German and Latin until the 1770 .

The work on electricity established Franklin's reputation as a first-rate "natural philosopher" in the Dutch Republic too. Petrus van Musschenbroek in 1759 addressed a reverential letter to Franklin in which he (at Franklin's request) supplied a list of authors who had written on electricity but added that "nobody had done more to unveil the mysteries of electricity than Franklin" himself. ${ }^{30}$ After 1760 , Franklin traveled to the Low Countries twice and extended his network of Dutch contacts to include, among others, Jean Allamand and other professors in Leiden. He later corresponded with the founders of the Batavian society of experimental philosophy in Rotterdam, which appointed him a corresponding member of the society in $1771 .^{31}$

Dutch researchers, meanwhile, made significant advances in the study of another sort of electrical phenomena: electricity in animals. It had long been known that some types of fish, such as sea torpedoes, Nile catfish or South American eels, were capable of exerting powerful numbing effects on other animals and even on humans. In the first half of the eighteenth century, the dominant explanation of this intriguing phenomenon was a mechanical one. According to this explanation, proposed by Réaumur in 1714, the contractions of the muscles of the fish could be related to elastic actions of tin "mechanical springs" in its body. ${ }^{32}$ However, a report by a British surgeon, Dale Ingram,

30 Petrus van Musschenbroek to Benjamin Franklin, 15 April 1759, in The Papers of Benjamin Franklin, 8:329.

31 Joost Mertens, "The honour of Dutch seamen: Benjamin Franklin's theory of oil on troubled waters and its epistemological aftermath," Physics Today 59, no. 1 (2006): 36-41; H. Hardenberg, "Benjamin Franklin en Nederland," Bijdragen voor de Geschiedenis der Nederlanden, 5 (1950-1951): 213-230, 215-217, 219-220; Franklin had a copy of the laws of the Batavian society and the first two volumes of its Transactions in his library, see Wolf and Hayes, The library of Benjamin Franklin, 109 nos. 239-240.

32 Peter Koehler, Stanley Finger and Marco Piccolino, "The 'eels' of South America: Mid-18th century Dutch contributions in the theory of animal electricity," Journal of the History of Biology 42 (2009): 715-763, 719, 723-724; Delbourgo, A most amazing scene of wonders, 176-180. 
who had lived in Suriname and who had personally experienced the shocking effects of the eel, suggested that a kind of "electrical energy or spring" might be involved. Ingram's account, which appeared in English and German journals in 1750, prompted one of the scholars who had assisted at the original Leyden jar experiment, Jean Allamand, to make further inquiries.

Allamand addressed himself to an old acquaintance from the days when he worked as tutor in the household of the Leiden professor of experimental philosophy Willem Jacob 's Gravesande, his nephew Laurens Storm van 's Gravesande. Storm van 's Gravesande was thoroughly at home in Dutch Guiana. He was first secretary to the then commander of Essequibo in 1738, and had a decade later risen to be director-general of Essequibo and Demerara. During a brief stay in the Netherlands in $175^{\circ}$ he had, with Allamand, experienced firsthand the powerful effects of the Leyden jar. Back in Essequibo, 's Gravesande penned a detailed reply to Allamand's inquiries about the eel in the Guiana rivers. The most striking part of his account, which Allamand published in 1755 in the transactions of the newly founded Hollandsche Maatschappij der Wetenschappen in Haarlem, concerned the resemblance between the effects of the eel and those of the Leyden jar. "If one touches the fish," 's Gravesande wrote, "[the eel] produces the same effect as the electricity that I felt with you, while holding in a hand the bottle that was connected to an electrified tube by an iron wire." 33

While Allamand and 's Gravesande did not yet state explicitly that the numbing effects of the eel were in fact an electrical phenomenon, and not a mechanical one, as Réaumur had claimed, this was the conclusion which Dutch scholars drew as more and more reports about the eel came in from Guiana and a specimen of the fish was carefully studied in Leiden. What particularly stimulated Dutch scholars was the arrival of an extensive account by Frans van der Lott from Essequibo (who had collaborated with Storm van 's Gravesande and who knew the effects of the Leyden jar firsthand) and the publication of a detailed description of the fish by Johan Frederik Gronovius' son, Laurens Theodoor. The prominence of Dutch scholars in research on this subject was no accident. The Netherlands was in the middle decades of the eighteenth century at the forefront of what the French nineteenth-century biologist Georges Cuvier called the transformation of the natural history of fishes into

33 Koehler, Finger and Piccolino, "The "eels" of South America," 727-731; Jean Nicolas Sébastien Allamand, "Kort verhaal van de uitwerkzelen, welke een Amerikaanse vis veroorzaakt op de geenen die hem aanraaken," Verhandelingen uitgegeeven door de Hollandsche Maatschappij der Wetenschappen te Haarlem, 2 (1755): 372-379; an English translation of this account is given in Koehler et al's article. 
"a truly scientific form." ${ }^{34}$ The leading ichthyologist of the 1730s, Peter Artedi, moved from Sweden via England to the Dutch Republic. His magnum opus Ichthyologia was posthumously published in Leiden by his compatriot Linnaeus, who had traveled to the Netherlands a few months before. ${ }^{35}$ Extensive collections of fishes from various parts of the world were built by Albertus Seba in Amsterdam and by Johannes Frederik and Laurens Theodoor Gronovius in Leiden. These collections, and Artedi's work, were the basis of a series of detailed case-studies and path-breaking general surveys on ichthyology, such as the Museum ichtyologicum, the Zoophylacium Gronovianum and the Locupletissimi rerum naturalium Thesauri accurata descriptio, published in the 175 os and 176 os. $^{36}$

The findings of the Dutch researchers soon became known in the scholarly world at large. Translations of the texts by Allamand, Van Musschenbroek, Gronovius and Van der Lott began to circulate in Latin and German in the late fifties, sixties and seventies. ${ }^{37}$ The first publication in English to affirm the electrical nature of the eel was a book on the natural history of Guiana by Edward Bancroft of Massachusetts, in 1769. Bancroft had worked as a physician in Essequibo between about 1763 and 1767 and he knew Van der Lott personally. According to James Delbourgo, his "experimental demonstrations of the eel's electricity closely followed those already conducted by the Dutch, from whom he had doubtless learned much."38 Bancroft's book triggered a wave of experiments and observations on electrical fishes both in colonial America and in England. David Rittenhouse, Ebenezer Kinnersley, Isaac Bartram and other fellows of the American Philosophical Society

34 Georges Cuvier, Historical portrait of the progress of ichthyology from its origins to our own time, ed. Theodore W. Pietsch, trans. Abby J. Simpson (Baltimore: Johns Hopkins University Press, 1995), 95-104.

35 Anne Wheeler, "Peter Artedi, founder of modern ichthyology," Proceedings V Congress of European Ichthyology, Stockholm 1985 (Stockholm: Swedish Museum of Natural History 1987), 3-10.

36 Cuvier, Historical portrait, 99, 105-107; Laurens Theodorus Gronovius, Museum ichthyologicum, 2 vols. (Leiden: Theodoor Haak, 1754-1756), idem; Zoophylacium Gronovianum, 3 vols. (Leiden: Theodoor Haak, 1763-1781); Albertus Seba, Locupletissimi rerum naturalium Thesauri accurata descriptio, 4 vols. (Amsterdam: Van Waesbergen, 1735-1765); Hendrik Engels' alphabetical list of Dutch zoological cabinets and menageries, ed. Pieter Smit (2nd ed. Amsterdam: Rodopi, 1986), 104-105, 249-250.

37 Koehler, Finger and Piccolino, "The 'eels' of South America," 745-746.

38 Andrew Bancroft, An essay on the natural history of Guiana in South America (London: T. Becket and P.A.de Hondt, 1769) 194-199; Delbourgo, A most amazing scene of wonders, $167,169-171,180-181$. 
carried out experiments with an electrical eel in Philadelphia in 1773, which were promptly reported to England. ${ }^{39}$ The crowning achievement was a series of experiments conducted by John Walsh in London in the 1770s at the instigation of Benjamin Franklin. Walsh was able to actually observe a spark at the moment when the eel discharged. This clinched the argument about the fish's electrical properties. In his eulogy for Walsh in 1775, the President of the Royal Society did not fail to make special mention of the contributions of the Dutch researchers. ${ }^{40}$

\section{Water, Winds and Currents}

Benjamin Franklin, meanwhile, turned his attention to other curious phenomena in the natural world, which in his view were particularly relevant for the shipping industry. The issues which caught his interest concerned the effect of oil on water and the pattern of winds and currents in the Atlantic. In his quest to solve these aquatic riddles, Franklin helped to bring two circuits of knowledge, which normally functioned in largely separate social spheres, together temporarily. These were the circuit of practitioners and the circuit of academics and members of learned societies, which were described in the introduction of this essay.

Contacts between these different circuits of knowledge in the Atlantic world as such were not unusual. Cadwallader Colden, for example, wrote in 1744 to Gronovius that he had learned from "Mohawk Indians" that "when they were quite faint with travel and fasting" their spirits could be "wonderfully" restored with the roots of particular plants. In another letter, he remarked that his "negroes told [him] that they have kinds of maize in Africa very different from any in this country." 41 Edward Bancroft described how he had called on Indians and slaves to assist in his inquiries about the natural history of Guiana. ${ }^{42}$ What was different in the case of the issues broached by Franklin, however, were the scale and the methods by which knowledge from various circuits were, at least temporarily, brought together. As with research on electricity, Dutch actors again played an important role in moving the process of inquiry forward.

\footnotetext{
39 Hindle, David Rittenhouse, 98-100; Stearns, Science in the British colonies, 615-616.

40 Koehler, Finger and Piccolino, "The 'eels' of South America," 746-750; Delbourgo, A most amazing scene of wonders, 196-198.

41 Colden to Gronovius (n.d., probably 1744), in Gray, ed., Selections from the scientific correspondence of Cadwallader Colden, 9-16, esp. 13-14, Colden to Gronovius, in idem, 29 October 1745, 16-18, esp. 17. 
Inquiries on the behavior of water were triggered by a contribution of Franklin to the Philosophical Transactions in 1774. In this brief essay, Franklin reported how during a voyage on a vessel in the British fleet headed for an assault on Louisbourg (Cape Breton) in 1757 he had observed that the wakes of two ships were smoother than the others and, when inquiring of the captain for the reason, he had been told that the phenomenon must have been caused by the greasy water emptied into the sea by the ships' cooks. Remembering later that, long ago, he had come across a remark in Pliny's Natural history that "everybody is aware that...all sea water is made smooth by oil," Franklin resolved, during his stay in England in the sixties and seventies, to find out more about the effects of stilling of waves by means of oil by carrying out a number of experiments. In addition, Franklin received some first- or secondhand accounts (including a letter by an official of the Dutch East-India Company) on the smoothing effects of oil observed by seamen or fishermen. Reflecting on these findings, Franklin suggested that oil could, under certain conditions, be usefully employed to diminish the wrinkling raising capacity of the wind, and thus smooth the waves and enhance the safety of ships and crews. ${ }^{43}$

Margaret Deacon, who summarized this account in her magisterial study on scientists and the sea, does not make mention of any follow-up to Franklin's publication. ${ }^{44}$ Actually, however, the report did cause a stir, and nowhere more so than in the Dutch Republic. The following chain of events shows again that colonial possessions were not a sine qua non for the role of Dutch actors in flows of knowledge. Cross-Atlantic networks of knowledge could thrive independently from the existence of colonial empires.

One of Franklin's experiments in London, at Green Park in 1773, was witnessed by three acquaintances with a Dutch background: Count Willem Bentinck, one of the most powerful noblemen in Holland and member of the governing board of the University of Leiden, his son John Bentinck, captain in the Royal Navy, and Jean Allamand. ${ }^{45}$ After returning to the Netherlands, Allamand repeated Franklin's experiments with the stilling effects of oil in a canal in Leiden in the presence of a number of friends: a retired naval captain, a natural philosopher and a merchant and cloth manufacturer, Frans van

43 Benjamin Franklin, William Brownrigg and Mr. Farrish, "Of the stilling of waves by means of oil," Philosophical Transactions of the Royal Society 64 (1774): 445-46o.

44 Margaret Deacon, Scientists and the sea 1650-1900. A study of marine science (London/ New York: Academic Press, 1971), 199-201.

45 Joost Mertens, "The honour of Dutch seamen: Benjamin Franklin's theory of oil on troubled waters and its epistemological aftermath," 4-5. 
Lelyveld. ${ }^{46}$ It was Van Lelyveld who brought the issue into the public square. He did so, first by making inquiries among friends, acquaintances and other interested persons scattered all over the maritime provinces of the Dutch Republic whether they knew anything about the practice of smoothing waves by pouring oil or a similar substance; secondly, by promising a reward for the best essay on the subject; and thirdly, by publishing, in 1775, a 200-page treatise containing all replies and reports, plus translations of selections from the writings on the topic by "the very famous English philosopher Benj. Franklin." This lengthy treatise was later translated into French. ${ }^{47}$ While preparing his publication, Van Lelyveld had written to Franklin himself asking him for "any emendations or additions" to his original piece. Van Lelyveld was particularly interested to know whether the use of oil on water was known among "fishermen and navigators" in colonial America too (as Franklin had been silent on this point in his original tract). ${ }^{48}$

The most important finding of Van Lelyveld's wide-ranging survey was that the practice of stilling waves by means of oil turned out to be not only known as far back as the time of Pliny, but was in fact still common knowledge among different groups of seamen and fishermen in Holland and in many other parts of the world, although this knowledge was spread unevenly among groups and groups in different localities were often not aware of its presence at other places. ${ }^{49}$ Knowledge did exist, but was localized. Van Lelyveld sent six copies of his treatise to Franklin, with kind regards from Allamand. ${ }^{50}$

Another issue that caught Franklin's interest concerned the behavior of winds and currents in the Atlantic. What patterns could be observed? How could these patterns be explained? Members of learned societies, especially in the English-speaking Atlantic world, had more than once engaged with those questions, but not in a sustained fashion. In the early days of the Royal Society the issue was discussed by, among others, Isaac Vossius and Edmond Halley. During his stay in England after 1670, Vossius published an English version of his book on winds, tides and currents, $A$ treatise concerning the motion of the seas and winds, which had first appeared as De motu marium et ventorum liber

\footnotetext{
46 Mertens, "Honour of Dutch seamen," 6-9.

47 Ibid., 7 .

48 Frans van Lelyveld to Benjamin Franklin, 9 December 1774, in The Papers of Benjamin Franklin, 373.

49 Frans van Lelyveld, Berichten en Prijs-vragen over het storten van olie, traan, teer, of andere dryvende stoffen, in zee-gevaren (Leiden: Johannes le Maire, 1775), 1-4, 14, 22, 40-42 and appendices $\mathrm{A}-\mathrm{K}$.

5o Van Lelyveld to Franklin, 11 March 1775, in The Papers of Benjamin Franklin, 519; Van Lelyveld to Franklin, 31 July 1777, in The Papers of Benjamin Franklin, 231.
} 
in Amsterdam in 1663. In this treatise Vossius refused to admit any motion of the seas and winds "which I could not if it were necessary confirm by infinite Testimonies and Experiments of sea men." ${ }^{.11}$ Edmond Halley in 1686 published a thematic map of the Northern and Southern Atlantic, which for the first time used showed rows of strokes (and sometimes arrowheads) as symbols to indicate the direction and strength of winds. This wind pattern according to Halley was repeatedly reproduced on English and Dutch charts in the first decades of the eighteenth century.52

Thanks to Franklin, interest in this issue revived in scholarly circles about 1770. Franklin suggested it might be useful for seafarers seeking fast passage across the Atlantic (such as captains of packet boats) to have a chart depicting "the Dimentions Course and Swiftness" of the current along the American coast commonly called by seamen "the Gulph Stream." At Franklin's request, a captain from Nantucket, Timothy Folger, marked the Gulf Stream on an existing chart, which was sent to the Post Office in London and printed by Mount \& Page in 1768. Revised versions of the chart were published by Franklin himself in 1782 and 1786, the latter one in the second volume of Transactions of the American Philosophical Society. Another chart of the Atlantic currents was published by an English physician, Charles Blagden in the transactions of the Royal Society in 1781. Systematic research on patterns of winds and currents in the Atlantic Ocean really started with the work of a former seaman and surveyor of the East-India Company, James Rennell, who collected a huge mass of data on every ocean of the world from ships' logbooks and other sources. Although his magnum opus on currents in the Atlantic Ocean was not published until 1832, some of his ideas and findings circulated in Britain (and beyond) long before that date. A Dutch translation of Rennell's observations on a current to the Westward of the Scilly islands, first published in the Philosophical Transactions in 1793, appeared in Amsterdam a year later. Added to the translation of Rennell's text were translations of selected parts from Blagden's article of 1781 and summaries of observations on the Gulf Stream published in an American magazine, The American Museum. ${ }^{53}$

51 Isaac Vossius, A treatise concerning the motion of the sea (London 1677 , facsimile edition, New York: Delmar 1993); "The Author to the Reader," H.J. Burstyn, "Theories of winds and ocean currents from the discoveries to the end of the seventeenth century," Terrae Incognitae. The Annals of the Society for the History of Discoveries 3 (1971): 7-31.

$5^{2}$ Arthur H. Robinson, Early thematic mapping in the history of cartography (Chicago/ London: University of Chicago Press, 1982), 46-48.

53 Deacon, Scientists and the sea, 220-222; Waarnemingen over een stroom welke dikwyls stand grypt ten westen van Scilly...door James Rennell... uit het Engelsch vertaald, en met 


\section{Facilities and Forces}

The growth of shipping in the North Atlantic and its increased regularity since the late seventeenth century was no doubt an important underlying factor that facilitated the emergence of transatlantic networks of knowledge. "The growing maritime commerce [between 1675 and 1740], particularly in the Leeward Islands, Jamaica, South Carolina, and Pennsylvania, increased the flow of transatlantic news and narrowed the space and time between colonies," Ian Steele has written. ${ }^{54}$ Communication thus became faster and more regular as traffic increased. The consequences of this change were not restricted to the English Atlantic world. Communication between British American colonies and regions outside the British empire became easier as well. Alexander Garden in Charleston remarked for example in a letter to Carolus Linnaeus in 1755 that there were four or five ships every year sailing from South Carolina to Rotterdam which could take mail.55

Although packet boat services between England and the West Indies were in operation on a regular basis since 1744, and between England and North America since $1755,{ }^{56}$ actors in transatlantic networks of knowledge commonly used other channels of communication to send each other parcels and letters. These circuits of exchange could only be maintained if it was easy to find people who could be trusted to deliver packages safely and promptly to the right destination. The persons whom members of the scholarly Atlantic regarded next to kinsmen, friends and fellow-scholars - as the most reliable carriers of messages, were merchants and, to a lesser extent, clergymen (or their relatives). The growth and persistence of the scholarly Atlantic was in this way not only supported by the expansion of shipping but also by the development of commercial networks. ${ }^{57}$ Johan Frederik Gronovius and his correspondents made mention in their letters of merchants whom they considered a safe pair of hands for the transmission of letters and packages. Lewis Johnston in the 1730 s asked Gronovius to leave packages in the care of "mr. Bernard van der

eenige Aantekeningen vermeerderd door Jacob Florijn (Amsterdam: G. Hulst v. K., 1794), esp. Introduction, $\mathrm{A}_{3}$ (and footnote) and Appendix.

54 Ian K. Steele, The English Atlantic 1675-1740. An exploration of communication and community (New York: Oxford University Press, 1986), 275.

55 Alexander Garden to Carolus Linnaeus, 15 March 1755, The Linnaean Correspondence, linnaeus.c18.net, letter L886 (consulted 17 July 2012).

56 Steele, The English Atlantic, 10. The first packet service to the West Indies, started in 1702, was discontinued after 1715. See Steele, chapter 9.

57 Cf. also Delbourgo, A most amazing scene of wonders, 18, 22. 
Grift," merchant at the Keizersgracht in Amsterdam. ${ }^{58}$ Gronovius himself relied for his safe correspondence on Hudig and Papin in Rotterdam and on Messrs. Van der Velde and Messrs. Van Zadelhoff in Amsterdam. ${ }^{59}$ Religious networks sometimes fulfilled a similar function as networks of merchants. There existed in the eighteenth century regular contacts between the Reformed Church in the Netherlands and Dutch-speaking Protestant communities in New York, New Jersey and Pennsylvania. ${ }^{60}$ Thus, Gronovius also sent messages to British America with Protestant ministers and a son "of the Archbishop of Uppsala."61

However, ocean shipping and commercial and religious networks should be seen as vehicles of communication rather than as the main driving forces of the development of circuits of knowledge. True, some members of the scholarly Atlantic, such as Colden, Logan, Franklin, Collinson or Van Lelyveld were entrepreneurs themselves. Others, such as Storm van 's Gravesande, were in the service of a chartered company. A few, such as Allamand, were trained as ministers of a Protestant church. A market for curiosities, instruments and publications on science and scholarship definitely did exist. ${ }^{62}$

$5^{8}$ Johnston to Gronovius, 20 November 1734, National Library of the Netherlands, The Hague, Ms. 121 D 6, no. 37.

59 Gronovius to Richardson, 2 September 1738, in Extracts from the literary and scientific correspondence of Richard Richardson, 375-380, esp. 375; Gronovius to Richardson, 7 December 1739, in idem, 381-382, esp. 381; Gronovius to Linnaeus, 11 November 1738, The Linnaean Correspondence, linnaeus.c18.net, letter Lo263 (consulted 27 July 2012); Gronovius to Colden, 6 August 1743, in Selections from the scientific correspondence of Cadwallader Colden, ed. Gray, 4-7, 6; Gronovius to Colden, 3 April 1744, in idem, 7-8 esp. 8.

6o Joyce D. Goodfriend, "The Dutch book trade in colonial New York City: The transatlantic connection," in Books between Europe and the Americas. Connections and communities, 1620-186o, ed. Leslie Howsam and James Raven (London: Palgrave Macmillan, 2011), 128156, esp. 134-146; Joseph H. Dubbs and William J. Hinke, The Reformed Church in Pennsylvania, part IX (Lancaster: The Society, 1902) chapter 7.

61 Gronovius to Colden, 6 August 1743, in Selections from the scientific correspondence of Cadwallader Colden, ed. Gray, 4-7, esp. 4; Gronovius to Bartram, 2 July 1750, in Darlington, ed., Memorials, 358; Gronovius to Bartram, 10 June 1754, in idem, 36o-363, esp. 361-362.

62 Cf. Cook, Matters of exchange, passim; Daniel Margócsy, "Advertising cadavers in the republic of letters: anatomical publications in the early modern Netherlands," British Journal for the History of Science, 42 (2009): 187-210; idem, "A museum of wonders or a cemetery of corpses? The commercial exchange of anatomical collections in Early Modern Netherlands," in Silent messengers: The circulation of material objects of knowledge in the Early Modern Low Countries, ed. Sven Dupré and Christoph Lüthy (BerlinMünster: LIT Verlag, 2011), 185-215. 
Yet there is no evidence that commercial or religious interests and values were the mainspring of the emergence and evolution of knowledge networks. Circulation of knowledge was facilitated by these factors, but was only partly caused by it.

To explain the structure and dynamics of the transatlantic circuits of knowledge we should also take the values, attitudes and informal codes of the Republic of Letters into account. The scholarly Atlantic was the Republic of Letters writ large. The creation and maintenance of transoceanic networks of knowledge offered substantial benefits to their members on both sides of the Atlantic. These benefits did not (primarily) consist in material rewards, but were mainly paid out in the form of status. The rules of the game were similar to those described by Anne Goldgar in her anthropology of the European Republic of Letters between ca. 1680 and $175^{\circ}$. The essential principles of the Republic of Letters were an ethic of cooperation and reciprocity, an ideal of openness and the assignment of status on the basis of merit (in the eyes of colleagues) plus the idea of primacy of harmony over religious and political dissension. ${ }^{63}$ Generosity could be more rewarding than striving for commercial gain. ${ }^{64}$

The principles of the Republic of Letters also underlay the development of the networks of knowledge in the North Atlantic in the eighteenth century. Although relations between, on the one hand, "colonial observers" in British American colonies and Dutch Guiana and, on the other hand, "metropolitans" in Britain and Continental Europe initially may have been unequal, ${ }^{65}$ such connections nevertheless could be beneficial for both sides, as we have seen. For colonials, being a valued supplier of specimens and information in regular correspondence with established scholars in Britain or Continental Europe served as a mark of distinction and provided them with admission to a larger scholarly world. For metropolitans, engaging in correspondence with colonials presented them not only with a useful source of "raw materials" for their own work but also enhanced their status among fellow-members of the scholarly world: the more clients and admirers, the higher the rank. Once admitted to the "club," colonials could attain a higher status on the basis of merit, too, as the case of Franklin proves.

\footnotetext{
63 Anne Goldgar, Impolite learning. Conduct and community in the Republic of Letters, 1680-1750 (New Haven: Yale University Press, 1995).

64 R.P.W. Visser, The zoological work of Petrus Camper (1722-1789) (Amsterdam: Rodopi, 1985), 48; Marc J. Ratcliff, "Abraham Trembley's strategy of generosity and the scope of celebrity in the mid-eighteenth century," Isis, 95 (2004): 555-575.

65 See for this distinction Delbourgo, A most amazing scene of wonders, 18-20.
} 
The idea that harmony among scholars should overrule religious and political differences, was strongly in evidence in the scholarly Atlantic as well. Even during wartime, scholars from different countries were supposed to maintain friendly relations as usual. During the War of the Austrian Succession, for example, John Bartram complained to Gronovius that "it was very discouraging to think that all [his] labour and charges" might fall into the hands of French or Spanish privateers, who would take "no further care of them than to heave them overboard into the sea. If [he] could know that they fell into the hands of men of learning and curiosity [he] would be more easy about them." Cadwallader Colden had found a practical solution: on the outside of his packet to Gronovius he had added a kind request in French, asking privateers to send the content "to the gentlemen of the Royal Garden in Paris." 66

This chapter has shown that Dutch actors, and especially scholars based in Leiden, played a significant role as creators and brokers of knowledge in the eighteenth-century Atlantic world. Remarkably, their role in the development and maintenance of networks of knowledge in the Atlantic persisted long after the Dutch Republic had entered its terminal phase as an economic and political power. How can this phenomenon be explained? Both generational and structural factors should be taken into account. The influence of Dutch scholars in Atlantic circuits of knowledge in the eighteenth century was in part a consequence of the peak in the international appeal of Dutch universities reached between ca. 1680 and $1730 .{ }^{67}$ The number of foreign students flocking to Dutch universities in that period was higher than ever before or since. In the first quarter of the eighteenth century, almost a third of all graduates of Dutch graduates came from abroad. ${ }^{68}$ Among the Dutch institutions of higher learning, the University of Leiden proved to be especially attractive to English-speaking students.

66 Bartram to Gronovius, 6 December 1745, in Darlington, ed., Memorials, 352-354, esp. 353, Colden to Gronovius, 30 May 1746, in Selections from the scientific correspondence of Cadwallader Colden, ed. Gray, 19-20, esp. 19.

67 For an overview of the Dutch infrastructure of knowledge in the seventeenth and eighteenth centuries, see Willem Frijhoff, La société néerlandaise et ses gradués, 1575-1814 (Maarssen: APA Holland, 1981) and Karel Davids, "Amsterdam as a centre of learning in the Dutch Golden Age, c. 1580-1700," in Urban achievement in early modern Europe: Golden Ages in Antwerp, Amsterdam and London, ed. Patrick O'Brien, Derek Keene, Marjolein 't Hart and Herman van der Wee (Cambridge: Cambridge University Press 2001), 305-323.

68 Frijhoff, La société néerlandaise et ses gradués, 98-99 and annexe 2. 
Of all students from the British Isles and North America in the Netherlands in the seventeenth and eighteenth century, nearly three-quarters took a degree in Leiden. Between 1680 and 1730, more than 860 Scottish students alone matriculated there. ${ }^{69}$

The "British wave" to the Dutch universities, especially Leiden, between 1680 and 1730 had long-term effects in two ways. First, it created a network of alumni in the English-speaking world on both sides of the Atlantic, who had a first-hand acquaintance with the Netherlands and could also act as carriers of Dutch cultural and intellectual influence. Esther Mijers has argued that the fact that Scotland became part of the European Republic of Letters was a result of its "cultural and institutional connections with the United Provinces."70 A number of correspondents in America and Britain in Gronovius' network, such as Lewis Johnston, Isaac Lawson, Richard Richardson and Phineas Bond, were alumni of Leiden University as well. ${ }^{71}$ Secondly, the presence of so many English-speaking students in Leiden offered an opportunity for Dutch students to learn and practice the English language. This probably explains why Johan Frederik Gronovius possessed such a good command of English. One of the striking aspects of Gronovius' correspondence is that he communicated with his British and American correspondents not in Latin or in French, but in English. Thus, the "old boys network" of the Leiden alumni formed significant social capital, which helped to underpin the role of Dutch actors in Atlantic circuits of knowledge.

In addition, there were factors that kept this role intact even after the attractiveness of the Dutch universities for English-speaking students had begun to decline after the 1730s. The Netherlands also boasted an abundance of cultural capital embedded in its infrastructure of knowledge: its libraries, botanical gardens, anatomical theaters, collections of instruments and cabinets of curiosities and publishing houses constantly turning out books for both foreign and domestic markets. A large part of this infrastructure remained in place until at least the last decades of the eighteenth century. Jean Allamand was still busily networking between foreign authors and Leiden publishers in the 1760 s and 1770 . The Gronovius collection of fish remained in Leiden till Laurens Theodoor's death in 1777 , when it became a prized object for foreign buyers. The natural history collection of Stadtholder

69 Ibid., 101, Esther Mijers, "News from the Republic of Letters": Scottish students, Charles Mackie and the United Provinces, 1650-1750 (Leiden: Brill, 2012), 39.

70 Mijers, "News from the Republic of Letters," 7.

71 R.W. Innes Smith, English-speaking students of medicine at the University of Leyden (Edinburgh: Oliver and Buyd, 1932), 26, 129, 138, 194. 
Willem V, founded in 1756 , was so highly regarded by scientists in France that they could hardly wait to have it entirely moved to France after the conquest of the Netherlands in $1795 .^{72}$

The growth and persistence of this extensive infrastructure of knowledge in the Dutch Republic was in no small measure due to the vast amount of private wealth amassed in the seventeenth and eighteenth centuries. Some of its citizens could easily afford to pay for costly publications out of their own pocket. The Amsterdam banker George Clifford published in 1738 the Hortus Cliffortianus, a systematic description of the plants in his private botanical garden made by Carolus Linnaeus, at his own expense, and refused to sell any copies on the market. The 200-odd copies distributed by 1739 were all given as gifts. When the first copies finally did come on the market via auctions, they fetched 28 guilders apiece. ${ }^{73}$ Johan Frederik Gronovius, with an estate valued at more than 63,00o guilders, financed the publication of Linnaeus' Systema naturae and his own Flora Virginica himself. ${ }^{74}$

Private wealth could be transformed into physical infrastructure for knowledge production too. A prime example is the Teylers Stichting, a learned institution in Haarlem founded in 1778 , which was funded from the immense fortune left by merchant-entrepreneur Pieter Teyler van der Hulst. The curator of the Stichting, Martinus van Marum, in 1783 managed to persuade the directors to order a huge electrical machine from the Amsterdam instrument maker John Cuthbertson, which for a long time was the most powerful one of its kind in Europe. Indeed, Teyler's device enjoyed such as high reputation in the scholarly world that scientists abroad, such as Alessandro Volta in Italy, sometimes expressly asked Van Marum to run particular experiments with his unique "grande machine electrique."75 In these ways, the past creation of wealth

72 Rietje van Vliet, "Makelaar in intellect. Johannes Nicolaas Sebastiaan Allamand (17131787) als intermediair tussen schrijvers en uitgevers," Tijdschrift voor Sociale en Economische Geschiedenis 1 (2004): 103-122; Hendrik Engels' alphabetical list, 104-105; Catalogue of fish collected and described by Laurence Theodor Gronow now in the British Museum (London: Woodfall and Kinder, 1854), v-vii; M. Lemire, "La France et les collections du stathouder Guillaume V d'Orange," in Een vorstelijke dierentuin. De menagerie van Willem V, ed. B.C. Sliggers and A.A. Wertheim (Zutphen: Walburg Pers, 1994), 87-114.

73 George Clifford to Carolus Linnaeus, 20 April 1739, The Linnaean Correspondence, linnaeus.c18.net, letter Lo28o (consulted 18 August 2012); Gronovius to Linnaeus, 12 July 1739, The Linnaean Correspondence, linnaeus.c18.net, letter Lo291 (consulted 18 August 2012).

74 Maarten Prak, Gezeten burgers. De elite in een Hollandse stad 1700-1780 (Amsterdam: De Bataafsche Leeuw 1985), 388.

75 W.W. Mijnhardt, Tot Heil van 't Menschdom. Culturele genootschappen in Nederland, 1750-1815 (Amsterdam: Rodopi, 1988), 302-306; Van Marum to Volta, 23 August 1785, in 
allowed Dutch actors to continue to play a key role in the production and circulation of knowledge independently of the status of the Netherlands as a colonial power in the Atlantic.

\section{Conclusion}

This chapter has focused on actors and their connections, more specifically on the role of Dutch actors in scholarly circuits of knowledge between Britain, the Dutch Republic and colonies in the Americas. The perspective has shifted from institutional forces such as imperial governments, religious organizations, trading companies and scientific societies to network-building by individuals, or groups of people, from below. What this approach reveals is that even if some participants were more equal than others, the structure of the networks of knowledge in the eighteenth century was polycentric rather than monocentric and did not show any kind of enduring hierarchy. Moreover, this different perspective has also allowed us to catch a glimpse of the networks' dynamics: circuits of knowledge in the North Atlantic became over time more integrated in a spatial sense, existing circuits of knowledge on a specific subject, such as plants, also went on to serve as channels for knowledge on other topics, such as fish or electricity, and circuits of knowledge which usually functioned in separate social spheres, e.g. those of scholars and seamen, could temporarily be brought together. In all these respects, Dutch actors played a much more significant part in the development and maintenance of knowledge networks in the North Atlantic than a top-down, institutional perspective would suggest.

The emergence and evolution of these knowledge networks was aided by the growth of shipping as well as by the development of commercial and religious networks, but they were not driven by these forces. Likewise, they could be connected to colonial possessions, but they were not necessarily dependent on their presence. To explain the structure and dynamics of the networks of knowledge, the values, attitudes and informal codes developed in the European Republic of Letters should be taken into account as well. In the eighteenth century, the Republic of Letters expanded in the Atlantic world irrespective of existing borders between different colonial empires.

In this scholarly Atlantic, Dutch actors played a significant role as creators and brokers of knowledge thanks to a combination of generational and structural factors. They could build both on the social capital formed in the heyday

La correspondence de A. Volta et M. van Marum, ed. J. Bosscha (Leiden: Sijthoff, 1905) 8-9; Volta to Van Marum, 26 July 1786, in idem, 17-18, Volta to Van Marum, 25 June 1787, 26-31. 
of English-speaking students to the University of Leiden between 1680 and 1730 and on the pre-existing, highly-developed infrastructure of knowledge in the Dutch Republic, as well as on the substantial wealth accumulated by its citizens. These factors may explain why Dutch actors continued to play a prominent role in the development and maintenance of networks of knowledge in the Atlantic long after the Dutch Republic had started to lose its status as a first-rate economic and political power. ${ }^{76}$

This essay has concentrated on connections between Britain, the Dutch Republic and British and Dutch colonies in the Americas, while showing along the way that the Netherlands in the eighteenth century in some respects served as a hub of knowledge for scholars from Sweden, France and Italy too. If we would expand the scope of the analysis to include all scholarly networks in the eighteenth-century Atlantic, the picture would doubtless be enriched, refined or modified at a number of points. On the one hand, we might expect to find many similarities to the patterns discussed above, given underlying constants such as the prevalence of values, attitudes and informal codes of the Republic of Letters or the persistence of the spatial location of cultural capital. On the other hand, we should not be surprised to discover that scholarly relations between France, French colonies and the Dutch Republic developed somewhat differently than the Anglo-Dutch connections discussed in this article. State agencies in France weighed more heavily in the accumulation and exchange of knowledge than in Britain, most Dutch scholars were more fluent in French than in English and French students did not flock to Dutch universities in the same numbers as students from England or Scotland. Spanish and Dutch networks of knowledge likewise showed interesting differences in structure and dynamics. ${ }^{77}$ The scholarly Atlantic, in short, will definitely benefit from further comparative research.

${ }_{7} 6$ A similar discrepancy has been observed in the field of technology. The Dutch Republic was still regarded as a technological leader in Europe long after the rate of technological innovation had begun to decline, see Karel Davids, The rise and decline of Dutch technological leadership. Technology, economy and culture in the Netherlands, 1350-180o (Leiden: Brill, 2008).

Davids, "Dutch and Spanish global networks of knowledge." 